\title{
Factors that affect rice crops price estimation based on grain mill enterprise in Ploso Jombang
}

\section{Anita Permatasari}

Faculty of Economy, Catholic University of Darma Cendika, Surabaya, East Java, Indonesia

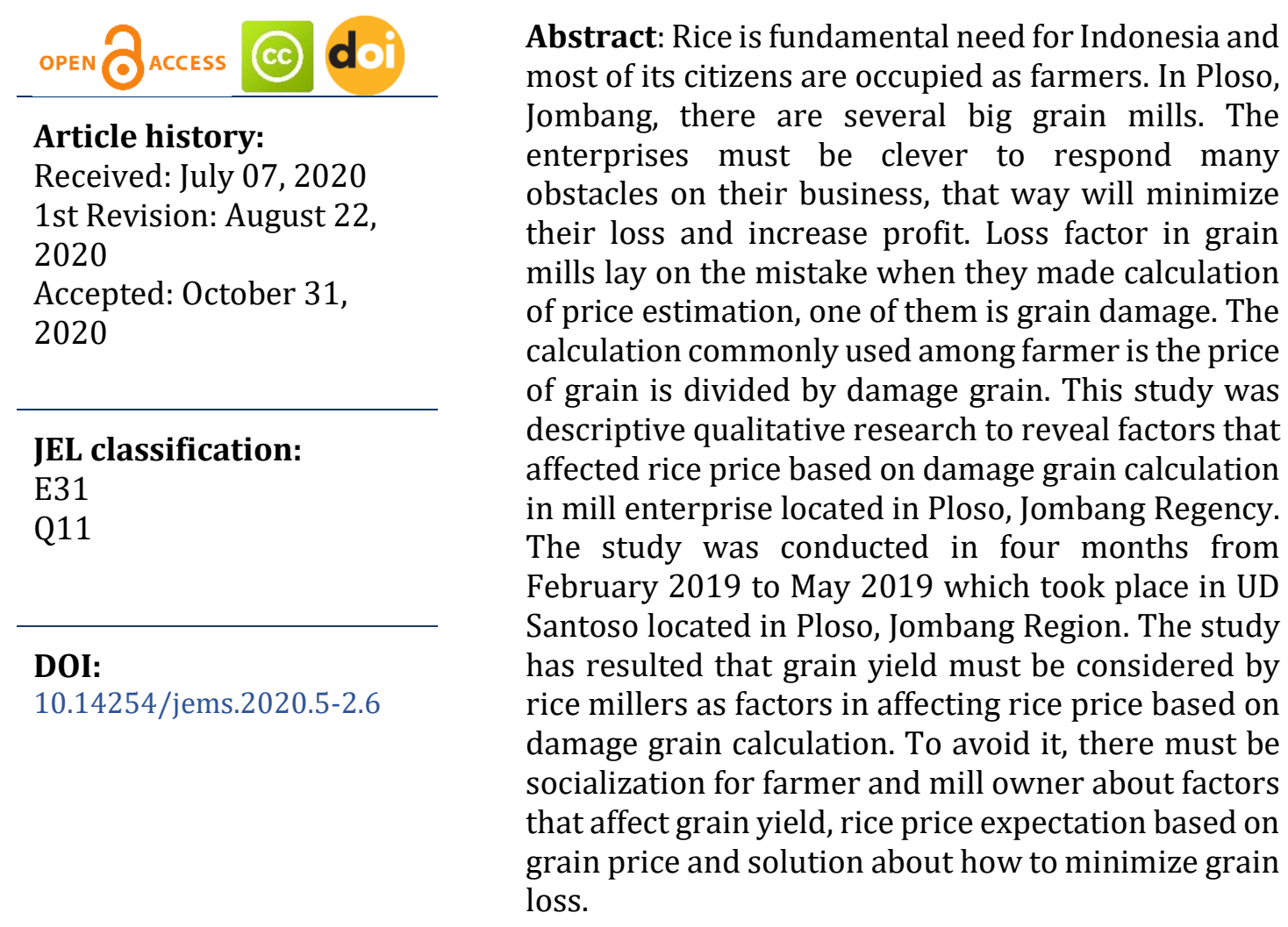

Keywords: damage grain, grain price, cracked kernels, rice price, enterprise.

\section{Introduction}

Indonesia is popular with agricultural industry, where Indonesia has countless number of fertile soil, tropical climate, it makes Indonesia become an ideal country to be agricultural center and turn its people to be farmer as their main occupation. Agriculture sector, in Indonesia, also becomes one of most important factor role in running the wheel of economic in Indonesia (Oktavia et. al., 2016). The existence of agriculture sector in Indonesia must be maintained and developed by government. Here are percentage data of community divided based on their occupation type. 
Table 1: The percentage of community based on their occupation type

\begin{tabular}{lccc} 
& \multicolumn{3}{c}{ Year / Period } \\
\cline { 2 - 3 } & $\mathbf{2 0 1 7}$ & $\mathbf{2 0 1 8}$ & $\mathbf{2 0 1 9}$ \\
\hline Agriculture & 29,68 & 28,79 & 27,33 \\
Trade & 18,57 & 18,61 & 18,81 \\
Grocery industry & 14,51 & 14,72 & 14,96 \\
Construction & 6,62 & 6,69 & 6,72 \\
Accommodation of food and beverage & 5,71 & 6,18 & 6,68 \\
Education & 4,94 & 4,89 & 4,99 \\
Other service & 4,96 & 4,85 & 4,97 \\
Transportation & 4,18 & 4,35 & 4,40 \\
Government administration & 3,79 & 3,78 & 3,85 \\
Healthcare & 1,47 & 1,29 & 1,54 \\
Enterprise service & 1,37 & 1,34 & 1,52 \\
Financial service & 1,43 & 1,45 & 1,39 \\
Mining & 1,15 & 1,17 & 1,13 \\
Information and communication & 0,68 & 0,72 & 0,72 \\
Water supply & 0,34 & 0,38 & 0,39 \\
Real estate & 0,25 & 0,32 & 0,32 \\
Electricity and gas & 0,25 & 0,27 & 0,28 \\
\hline SOurce: Statistic Center & & & \\
\hline
\end{tabular}

Source: Statistic Center (2019)

The Table 1 shows that farmer occupation is the most chosen occupation by citizens of Indonesia rather than another sector. Table 1 also reveals that, from 2017 to 2019 agriculture sector percentage is decreasing for $2,35 \%$, while other sector experience increasing small number of percentages from 2017 to 20198 . The data tell us that agriculture sector trend is declining. It is caused by the number of fields that keep transforming into another industry.

One of agriculture product of Indonesia is grain that will be later milled into rice. Rice is the most basic need for Indonesian people. The greater number of people, the more demand that need to be fulfilled (Srirande, 2012). Increasing number of demands had forced Indonesian government to increase the productivity in order to answer all the demands.

Rice consumption level per capita for a week, according to statistic institution center in 2016 is 1,668 , it is 1,565 in 2017, it is 1,551 in 2018. The number is higher than corn grain consumption which is 0,035 in 2016, it is 0,026 in 2017, it is 0,019 in 2017, and it is 0,019 in 2018. The data also show us that rice consumption in a week per capita is decreasing annually from 2016 to 2018 . In the other hand, corn grain and milled corn experience positive trend from 2016 to 2018.

In Ploso, Jombang Regency, most people are mainly occupied as farmer with several big grain mill enterprises, one of them is UD Santoso. The competition between mills enterprise are tightening nose. It is caused by the rice price that become very stable and high stable among farmers. Increasing price of grain is a common event among mills entrepreneur that must be overcame, but if the increasing price is always high and keep on its course, it will threaten the existence of small mill enterprise. It will affect their buying power because of limited capital they possessed.

These threats must be overcame by assuming the estimation of their loss among mills enterprise. One of technique to minimize loss is to proper rice purchase planning and clear financial calculations records. Proper rice calculation could use formula of counting rice price based on grain damage.

According to introduction of background of problems explained above, this study discussed the factors that affected rice price based on damage grain calculation in mill enterprise located in Ploso, Jombang Regency. This study aimed to reveal factors that affected rice price based on damage grain calculation in mill enterprise located in Ploso, Jombang Regency. Practically significant, this study helped to provide reliable information for mill enterprise owner to minimize their loss and recover post-harvest condition in Ploso, Jombang Regency and to communicate larger audiences on particular events related to this study.

\section{Materials and methods}

This study was descriptive qualitative research whereas the research procedure was executed to create descriptive data which is displayed in verbal or in written (Moleong, 2012) and it was synchronized between researcher and informants. Type and source of data of this study were using primary and secondary data. Primary data was carried out by using direct interview with the owners 
of mill enterprise and in depth-review with administration staff and purchasing. Secondary data was obtain from rice sale and purchase staff. Data collection technique was using observation, interview, and documentation. The setting of study was conducted in four months from February 2019 to May 2019 which took place in UD Santoso located in Ploso, Jombang Region.

\section{Results}

Based on result of interview, UD Santoso estimates rice of rice based on grain price. Before taking on the calculation, there are several factors that must be revealed related to the grain. There are several factors that affect quality of grain. First, the climate; the climate condition could affect quality of grain. In summer, field of rice will lack of water level on its grain and it will wane drastically. In rainy season, where there is a lot of water, grain seed will turn a little black and the seed does not in clean white anymore. Second, pest control; controlling pest and insect is one of most important that must be considered by farmers. As it will affect most of grain quality. It could disrupt working performance of the vegetation and intercept the growth of it or it even will stop the growth and will result in worse grain quality. Third, variety of rice; an interview result with purchasing staff has resulted three types of rice, namely:

a) Ciherang Variety (INPARI 32 HDB characteristic)

Characteristics of INPARI 32 HDB is the harvest age is 120 days, it grows as tall as $97 \mathrm{~cm}$, it has slim and firm limb. That is why, this kind is the most favored type among farmers. INPARI 32 HDB is known for its strong protection from pest and insects.

b) INPARI 33 Characteristic

Characteristic of INPARI 33 is that it has 102 days of harvest age within height as tall as $93 \mathrm{~cm}$, the branch is firm with greenish leave, it has high grain. INPARI 33 is expected to be next generation of excellent breed.

c) INPARI 43 Agritan GSR Characteristic

Characteristic of INPARI 43 GSR is that it stood as tall as $88 \mathrm{~cm}$, it has firm posture within long leave in the middle, it is used to cover the grain from bird attack. It has best taste when cooked than other breeds.

Forth, the fertilization technique and type; the use of a technique, control, and observation on fertilization process will affect the grain quality. Fifth, post-harvest technique; in this phase, rice should be harvested according to the age of the plant. The characteristic of rice that is ready to be harvested is that the grains of rice already look yellow. Delay in rice harvest or too fast rice harvest will have an impact on the decrease in grain yield. In the same context, changes in post-harvest rice can affect the chemical, physicochemical and functional properties of rice itself. Storage temperature and moisture content are one of the factors that can influence the changes in grain properties. The higher temperature and water content in the grain will cause greater changes in the grain, (Chrastil, 1990). Damage to the grain can be minimized if water and temperature levels are controlled. High water content will cause the growth of microorganisms, insects and termites during the grain is stored.

After the rice harvest is finished, the final stage that must be considered is the post-harvest technique, for example such as the water content in the grain is a maximum of $14 \%$ and when the grinding machine is in good condition, Wijaya (2009). The higher the water content of the grain, the grain has perishable characteristics and will experience a lot of shrinkage during post-harvest handling and processing time. It is also one of the factors that can cause losses or a reduction in the income of rice mill entrepreneurs, (Kartasapoetra, 1994).

Correspond to it, Milled grain is annually decreasing. In 70's, the percentage of milled grain quantity is $70 \%$, it decreases into \% in 1985, it decreased into 63,2\% in 1999, in 2000 the highest percentage is $63 \%$, and it turned into $60 \%$ in actual field mill (Tjahjohutomo, 2004). However, there are several kinds of grain sold by farmers in this study's investigation, namely:

1. Dry Milled Grain

Main characteristics of dried milled grain are:

a. It has maximum water level of $14 \%$. If the amount of water level exceed the minimum point, it will make the grain fragile and torn into pieces.

b. Milled dry grain is about 60 to $65 \%$. The number tells us that if the dried grain is milled, the remaining $35-40 \%$ of the result will turn into bran both soft and sturdy bran.

2. Harvested Dry Grain 
Main characteristics of harvested dry grain is the high water level which is 22,9\% until 29,1\% (Ashar dan Iqbal, 2003). The high water level will increase effectiveness of the enzyme (Dhaliwal et al., 1991), thus it is important to make correct room temperature to avoid damaged grains grow rapidly, (Millati et al., 2017).

3. Stored Dry Grain

The characteristic is the water level is between $14 \%$ and $18 \%$.

\section{Discussion}

Up to 80 and 85 percent content of rice is dominated by starch (Winarno, 1997). Rice also contains several vitamin located in aleuronic, protein, mineral, and water. Starch rice is made of two polymer carbohydrate which are amylose and amylopectin, the percentage amount between amylose and amylopectin will decide the color of rice, transparency, watery, sturdy, or the 'pera' of rice (Damardjati, 1995). However, there are two classifications of rice, namely brown rice and milled rice.

Brown rice is the product of grin which is only use part of its rice hulls and does not transformed into white rice (Hendrawan et al., 2017). Brown rice and white rice possessed same amount of protein, calories, and fat. The difference of them is just on its milling process. Brown rice shell will be further processed using a polishing tool, so that the layer of aleuronic in rice will be lost. One of the factors that can affect the diversity of quality and results of milling is the size and shape of the seeds, resistance to cracks and resilience, thickness of the caryopsis wrapper, composition and distribution of rice components (Haryadi, 2006). Fat content of brown rice is higher than white rice as much as 1,6\%-2,8\% for brown rice and 0,3-0,5\% for milled rice. High fat content in brown rice will make decomposing process become faster during in silo (Koswara, 2009).

The last classification is Milled rice. Milled rice is the process of taking off rice hulls in order to take the white edible part (Hendrawan et al., 2016). The process will create two parts which are edible white part of rice and bran. The more white color of rice the lesser nutrition content in it. Regards to rice quality, there are several qualities of rice, which are SNI, cook quality, and taste quality. Here are two specification of rice quality based on SNI 6128:215 as follows:

(1) General specs that rice must be free of insects and chemical issue, does not smell, sour, or other uncommon smell, bran free grain, and free of dangerous chemical content.

(2) Specific specs that include hull angle, water level, the size of rice head, small rice cut, red cut, yellow cut, or vaporized small cut.

Mill entrepreneurs generally receive rice harvest from farmers in the form of dry grain harvest (GKP). Farmers will receive lower income if the farmer sells harvested unhusked rice, and conversely the farmer will receive higher income if he sells his unhusked rice in the form of dry unhusked rice (GKG) or stored dry unhusked rice (GKS). Supriatna (2003) states that the sale of harvested unhusked rice (GKP) by farmers is caused by several factors, such as: the need for farmers who are urging, the farmers do not have adequate drying and storage facilities. These factors will cause the price of grain to experience a price decline at the time of harvest.

UD Santoso used the measurement method in grain drying shrinkage by comparing grain weight before and after drying. Grain drying is done by drying the grain in the sun. Grain drying is carried out on average for two working days. After drying, the grain will be put back into the sack. Depreciation will increase if drying the grain is done on a tarpaulin base. This is similar to what was stated by Patiung (2015). UD Santoso, drying in the drying floor made of cement which has a slope, so that the dried grain is dried faster and the less grain left behind. At the time of accumulation of rice, shrinkage occurs when the accumulation of rice does not use a good base. Grain that is scattered when moving piles is also a shrinkage that is not avoided.

Here is example of rice price estimation based on grain.

\section{(a) Example 1}

Milled rice grain price is Rp 4.500 per kilo and the agreement for grain percentage is $65 \%$. Then, the rice price per kilo would be defined as:

Rice price $=$ grain price divided by grain percentage

Rice price $=\operatorname{Rp} 4.500: 65 \%=\operatorname{Rp} 6.923$ per kilo.

Then the rice price is $\mathrm{Rp} 6.923$, it is time for the entrepreneur to compare it with recent rice price in market. After revealing the comparison, the miller will decide whether they will sell the rice or the grain. 


\section{(b) Example 2}

Dry grain price is Rp 4.000 per kilo within grain percentage of $62 \%$. Sale price on market for rice is Rp 7.500 per kilo. It is time to decide whether they will sell the rice or the grain.

Rice price $=$ grain price divided by grain percentage

Rice price $=\operatorname{Rp} 4.000: 62 \%=\operatorname{Rp} 6.542$ per kilo.

The price of rice from the seller for rice is Rp 6.542 per kilo, and the stock market price for rice is Rp. 7.500 per kilo. It means that there is price gap as much as $\mathrm{Rp} 1.048$ per kilo. Thus, the mill owner will tend to sell the corps as rice.

\section{(c) Example 3}

The mil is grinding dry milled grain as many as 1 ton within 600 kilogram of rice, it means that the grain percentage is $60 \%$. Here is the way to calculate grain percentage: gross weight of grain is divided by rice weight and multiplied by 100 percent.

Grain percentage $=(600 \mathrm{Kg}: 1000 \mathrm{Kg}) \times 100 \%=60 \%$

Interview result from UD Santoso revealed that there are several things in order to minimize the loss in mill enterprise, namely:

1. Harvest Age Estimation

It is expected for farmer to harvest their corps at optimum age within golden yellowish had been spotted in all field.

2. Harvesting Process

Harvesting the grain is commonly performed by farmer whereas they must be careful in using the machine. Postponed harvesting time will trigger many negative things such as grain loss while on road or eaten by pest, it must be followed by increasing number as much as $3 \%$.

3. Drying process

There are two methods of drying technique, most commonly used by farmers is by using sun light. Second method uses artificial dryer by using grain shell as its heat source material.

4. Storing

Grain storing must be clear, UD Santoso uses plastic bag and stored in warehouse within controlled humidity in order to repel insect and pest attack. Stored grain will be kept until next harvest moon.

5. Milling

It is process to separate rice from its hulls. Polish process in rice will affect rice quality. Quality control is essential in this phase, and it is expected for the enterprise to use the method. On the other hand, milling process will decide the quality and quantity of result, damage during drying and while in silo. The grain could be harvested based on the age of it and water level. Most important part in drying grain is the time efficiency which is directly affected by the temperature of environment. Uncontrolled drying process while it is still fresh will make rice become more vulnerable and fragile. It is known as casehardening process.

\section{Conclusion}

The factor that must be considered by rice millers is grain yield itself. Grain mill businessman must be able to examine carefully the yield of grain that will be purchased will produce profits for the company or will cause harm to the company. Prediction errors in grain yield will be fatal in determining the calculation of rice prices. As recommendation, there must be socialization for farmer and mill owner about factors that affect grain yield, rice price expectation based on grain price and solution about how to minimize grain loss.

\section{Acknowledgment}

This is to certify and honor UD. Santoso for the kindness and readiness to be interviewed and elaborated any opinion and knowledge concern the researched topic.

\section{Funding Information}

This study is not funded by any scholarship and other funding supports. 


\section{Conflict of Interest}

It is to declare that there is no any conflicting interest in this study.

\section{Appendix A. Supplementary material}

Supplementary data associated with this article can be found, in the online version, at https://doi.org/10.14254/jems.2020.5-2.6

\section{Citation information}

Permatasari, A. (2020). Factors that affect rice crops price estimation based on grain mill enterprise in Ploso Jombang. Economics, Management and Sustainability, 5(2), 96-102. doi:10.14254/jems.2020.5-2.6

\section{References}

Ashar, A., \& Iqbal, M. (2013). Penanganan pasca panen berbagai varietas padi. Jurnal Galung Tropika, 2(1), 55-59. https://doi.org/10.31850/jgt.v2i1.

Badan Pusat Statistik. (2019). Keadaan Ketenagakerjaan Indonesia Agustus 2019, No. 91/11/Th. XXII, pp. 1-20.

Chrastil, J. (1990). Protein-starch interactions in rice grains. Influence of storage on oryzenin and starch. Journal of Agricultural and Food Chemistry, 38(9), 1804-1809. https://doi.org/10.1021/jf00099a005.

Damardjati, D. S. (1995). Karakterisasi sifat dan standarisasi mutu beras sebagai landasan pengembangan agribisnis dan agroindustri padi di Indonesia. Jakarta: Badan Litbang Pertanian.

Dhaliwal, Y., Sekhon, K., \& Nagi. (1991). Enzimatic activities and rheological properties of stored rice. Cereal Chem, 68(1), 18-21.

Haryadi. (2006). Teknologi pengolahan beras. Yogyakarta: UGM Press.

Hendrawan, A., \& Djoyowasito, M. (2016). Pengkajian beras pecah kulit (brown rice) dalam kemasan vakum (vacum packaging) berdasarkan ketebalan plastik kemasan jenis nylon. Jurnal Keteknikan Pertanian Tropis dan Biosistem, 4(3), 250-261.

Kartasapoetra, A. G. (1994). Teknologi penanganan pascapanen. Jakarta: Rineka Cipta.

Koswara, S. (2009). Teknologi pengolahan beras (teori dan praktek). Ebook pangan.com

Millati, P., Bintoro, \& Utami. (2017). Pengaruh suhu penyimpanan pada gabah basah yang baru dipanen terhadap perubahan mutu fisik beras giling. AGRITECH, 3(4), 478-485. https://doi.org/10.22146/agritech.12015.

Moleong, L. J. (2012). Metodelogi penelitian kualitatif. Bandung: Remaja Rosdakarya.

Oktavia, H. S. (2016). Peranan sektor pertanian dalam pembangunan ekonomi di Provinsi Jawa Timur $\begin{array}{llll}\text { (pendekatan input-output). Jurnal } & \text { 72-84. }\end{array}$ https://doi.org/10.21776/ub.habitat.2016.027.2.9.

Patiung. (2015). Strategi mengurangi kerugian pasca panen melalui pengembangan teknologi di Kabupaten Tuban. Jurnal UWKS, 15(2), 93-102. https://doi.org/10.30742/jisa.v15i2.504.

Srirande. (2012). Pertumbuhan provinsi agraris. Jakarta: Kencana.

Supriatna, A. (2003). Analisis sistem pemasaran gabah dan beras (studi kasus petani padi di Sumatra Utara). Bogor: Puslitbang Sosek Pertanian. 
Tjahjohutomo, R., Handaka, H., \& Widodo, T. W. (2004). Pengaruh konfigurasi mesin penggilingan padi rakyat terhadap rendemen dan mutu beras giling. Jurnal Enjiniring Pertanian, II(1), 2327.

Winarno, F. G. (1997). Kimia pangan dan gizi. Jakarta: Gramedia Pustaka Utama.

Wijaya. (2009). Pengaruh kadar air terhadap mutu fisik beras giling. Accessed on http://fapertausnwagati.com.

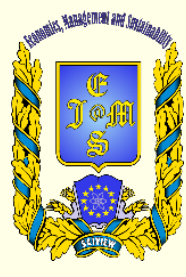

(c) 2016-2020, Economics, Management and Sustainability. All rights reserved.

This open access article is distributed under a Creative Commons Attribution (CC-BY) 4.0 license.

You are free to:

Share - copy and redistribute

The licensor cannot revoke these freedoms as long as you follow the license terms.

Under the following terms:

Attribution - You must give appropriate credit, provide a link to the license, and indicate if changes were made.

You may do so in any reasonable manner, but not in any way that suggests the licensor endorses you or your use.

No additional restrictions

You may not apply legal terms or technological measures that legally restrict others from doing anything the license permits.

Economics, Management and Sustainability (ISSN: 2520-6303) is published by Scientific Publishing House "CSR",

Poland, EU and Scientific Publishing House "SciView", Poland

Publishing with JEMS ensures:

- Immediate, universal access to your article on publication

- High visibility and discoverability via the JEMS website

- Rapid publication

- Guaranteed legacy preservation of your article

- Discounts and waivers for authors in developing regions

Submit your manuscript to a JEMS at http://jems.sciview.net or submit.jems@sciview.net 